\title{
Chemical composition of the far eastern homogenate of drone brood
}

\author{
Anna Prikhodko, ${ }^{1,}$, Olga Yankina $^{1}$, Natalya Kim ${ }^{1}$, Guli Koltun ${ }^{1}$, and Andrey Skolov ${ }^{2}$ \\ ${ }^{1}$ Primorskaya State Academy of Agriculture, pr. Blyukhera, 44, Ussuriysk, Primorsky Territory, \\ 692510, Russia \\ ${ }^{2}$ LLC «Taiga honey»
}

\begin{abstract}
This paper studies the chemical composition of the drone brood homogenate produced in the Primorsky Territory in comparison with the regulatory requirements and the results obtained in other regions. The composition of the homogenate was determined in the laboratory of the Pacific Institute of Bioorganic Chemistry, Vladivostok. The analysis showed that the chemical composition varies significantly for most indicators.
\end{abstract}

\section{Introduction}

A bee family is a structurally complex economic and biological unit. Drones play a seasonal role in it, which is associated with their only function - the fertilization of the queen. The largest number of drones is hatched mainly in spring and early summer, but drone brood is present during the entire active beekeeping season. The number of drone brood depends on a number of factors: the age and origin of the queen, the strength of the family, the period of the active season, the volume of the average daily collection of nectar and pollen, the provision of the family with protein feed, the number of combs with drone cells in the total volume of the nest.

Today, during the active beekeeping season, drone brood is destroyed in most apiaries to reduce the number of bees infected with varroa mite. However, drone brood homogenate (hereinafter $\mathrm{DBH}$ ) can be a valuable source of essential amino acids, fats, carbohydrates, macro- and microelements, and hormones.

According to research by a number of authors, native DBH contains $70.3-73.6 \%$ of moisture, $3.5-3.8 \%$ - lipids, $8.12-10 \%$ - protein, $38.81 \%$ - amino acids, including free ones $8,76 \%$, out of 20 available amino acids, 9 are irreplaceable [4,7,11,19,21]. Carbohydrates are represented mainly by glucose and sucrose; their share reaches 7.88 and $8.22 \%$, respectively [19]. Calculations by Valery A. Isidorov et al. showed that this product has a high calorie content - $501.4 \mathrm{kcal}$ in $100 \mathrm{~g}$ [7].

When studying the chemical composition of DBH, Valery A. Isidorov et al., Roża Sawczuk et al. compared the homogenate with royal jelly. The authors concluded that they have a similar set of substances, but different amounts. They note that royal jelly contains more proteins and amino acids, lipids and carbohydrates than a homogenate. The analysis

\footnotetext{
* Corresponding author: annaprikhodko2805@gmail.com
} 
of the quality of the protein showed that the such amino acids as isoleucine, lysine, methionine and phenylalanine are absent in DBH [7,19]. However, Lazaryan D.M., Sotnikova E.M. (2002) found in their studies that these amino acids are present in the homogenate of drone brood $[11,12]$. The disaccharide trehalose is the predominant sugar in royal jelly, while glucose predominates in DBH [18].

The drone brood homogenate obtained from 15-16 day old pupae contains $15.6 \mathrm{nmol} / \mathrm{l}$ of testosterone and $343.5 \mathrm{nmol} / \mathrm{l}$ of estradiol, and has a more pronounced gonadotropic activity than royal jelly, which allows restoring the blood concentration of testosterone and fructose [4].

A.B. Seres et al. studied the androgenic effects of drone milk in male rats. According to their studies, unrefined drone milk increased the relative mass of androgen-dependent organs and plasma testosterone levels in castrated rats, and these actions were sensitive to flutamide, and also increased mRNA in tissue and SLAP protein levels, which was further evidence of its androgen-like nature [20].

In many countries of the world (Japan, China, Romania, etc.), drone brood homogenate is the basis for dosage forms, in the production of cosmetic products, food additives, etc. For example, the cream "Apilar", powder additive "Bilar" are produced on its basis [20].

I. I. Klishina (2003) conducted studies on the influence of drone brood on the activity of nonspecific resistance factors and the functional state of the liver in acute intoxication. As a result, she concluded that the homogenate has a pronounced hepatoprotective effect on animals [10].

In recent years, $\mathrm{DBH}$ has found wide application not only in medicine, but also in agriculture. Its positive effect on the productivity and physiological state of farm animals, poultry, bees and dogs has been proven in the works of Muravyov D.V. (2016), Kataev O.G. (2018), Sattarova A.A. (2010), Osintseva L.A., Efanova N.V., Kabysheva V.V. (2019), Kim N.A. et al. (2019) $[8,9,15,17,18]$.

Primorsky Territory is one of the leaders in the production of honey, and beekeeping is one of the most developed branches of agriculture in the Russian Federation. One of the largest producers of honey in the region is the apiary of Taezhny Med LLC located in the Anuchinsky District of the Primorsky Territory of the Far Eastern Federal District. It is the only apiary in the region producing homogenate of drone brood, which is in demand among the population.

In this regard, the purpose of our study was to determine and compare the chemical composition of the drone brood homogenate obtained under the conditions of an apiary of Taezhny Med LLC for compliance with the requirements of the Russian State Standard GOST R 56668-2015 and data from literary sources.

\section{Materials and Methods}

First of all, literary sources (Scopus, CyberLeninka, eLibrary information bases) were studied. Further, laboratory studies were carried out to determine the chemical composition of the drone brood homogenate produced at the Taezhny Med LLC apiary in the accredited laboratory of the Pacific Institute of Bioorganic Chemistry, Vladivostok. Homogenate samples were taken in accordance with the requirements of Russian State Standard GOST R 56668-2015 in the period from 15.05.2019 to 18.06.2019.

\section{Results and discussion}

Table 1 shows the results of laboratory studies of the native homogenate of drone brood and the data from the literature taken for comparison. 
Table 1. Chemical composition of drone brood homogenate.

\begin{tabular}{|c|c|c|c|c|}
\hline Indicator & $\begin{array}{c}\text { GOST R } \\
56668-2015\end{array}$ & $\begin{array}{l}\text { Laboratory } \\
\text { results }\end{array}$ & Literature $^{\mathrm{a}}$ & Literature $^{b}$ \\
\hline Appearance: & $\begin{array}{l}\text { Homogeneous } \\
\text { mass }\end{array}$ & $\begin{array}{l}\text { Homogeneous } \\
\text { mass, }\end{array}$ & & - \\
\hline color, & $\begin{array}{l}\text { White to } \\
\text { cream }\end{array}$ & Cream & - & - \\
\hline consistency, & Liquid & Liquid & - & - \\
\hline mechanical impurities, & Not allowed & No impurities & - & - \\
\hline smell & & Brood-specific & - & - \\
\hline $\begin{array}{l}\text { Mass fraction of water, } \% \text {, } \\
\text { no more }\end{array}$ & 72.00 & 72.0 & $70.3-72.3$ & 73.6 \\
\hline $\begin{array}{l}\text { Indicator of oxidizability } \\
\text { (authenticity), s, no more }\end{array}$ & 16.00 & 14.00 & - & - \\
\hline $\begin{array}{l}\text { Hydrogen index }(\mathrm{pH}) \text { of an } \\
\text { aqueous solution by mass } \\
\text { fraction of } 2 \% \text {, not less }\end{array}$ & 5.80 & 7.2 & $6.23-6.63$ & - \\
\hline $\begin{array}{l}\text { Mass fraction of decenoic } \\
\text { acids, } \% \text {, not less }\end{array}$ & 2.5 & 12.0 & - & - \\
\hline $\begin{array}{l}\text { Mass fraction of crude } \\
\text { protein, } \% \text {, not less }\end{array}$ & 25.0 & 44.5 & $8.12-10.0$ & 10.0 \\
\hline Protein, $\%$ & - & 22.0 & - & - \\
\hline $\begin{array}{l}\text { Mass fraction of wax, } \% \text {, no } \\
\text { more }\end{array}$ & 0.10 & 0.08 & - & - \\
\hline Total carbohydrates, $\%$ & - & - & $6.22-8.22$ & 12.0 \\
\hline Lipids, \% & - & - & - & 3.5 \\
\hline
\end{tabular}

Based on the results of data on the chemical composition of the drone brood homogenate, it can be concluded that the quality of this preparation fully met the requirements of GOST R 56668-2015. Attention is drawn to the high content of crude protein and decenoic acids. Decenoic acids have an antibacterial effect against a number of pathogenic microorganisms $[2,3,16]$. These biologically active compounds are also found in royal jelly, whose antibacterial effect has been confirmed by studies [13, 14].

Comparing the actual composition of the homogenate with literary sources, the following can be noted: there is no single list of indicators that are monitored in DBH, only the mass fraction of moisture, crude protein and hydrogen index $(\mathrm{pH})$ were common. The organoleptic indicators, the authenticity indicator, and the mass fraction of wax were not determined by the authors of the literary sources used by us. In addition, GOST R 566682015 does not standardize the content of carbohydrates and lipids in the drone brood homogenate.

The moisture content in the test sample almost coincided with the data given by Balkanska et al. (2014), Yankina et al. (2017) and differed slightly (by 1.6\%) from the results obtained by Isidirov et al. (2016). The $\mathrm{pH}$ was 0.57-0.97 higher than that of Balkanska et al. (2014). It is necessary to note a significant difference in the content of crude protein. It was 4.45 times higher in the studied sample. Perhaps this is due to the technology of obtaining a homogenate $[1,7,22]$.

The mineral composition of the homogenate obtained under the conditions of Taezhny Med LLC is presented in Table 2. 
Table 2. Mineral composition of drone brood homogenate, $\mathrm{mg} / 100 \mathrm{~g}$.

\begin{tabular}{|l|c|c|}
\hline \multicolumn{1}{|c|}{ Indicators } & Laboratory results & Literature $^{\text {ab }}$ \\
\hline Calcium & $175-181$ & $13.8-16,0$ \\
\hline Phosphorus & $11.2-12.4$ & 179.0 \\
\hline Iron & $4.03-4.22$ & $1.6-4.2$ \\
\hline Manganese & $0.24-0.26$ & $0.06-0.14$ \\
\hline Magnesium & $940-1000$ & $21.1-30.8$ \\
\hline Sodium & $410-430$ & $12.8-30.2$ \\
\hline Potassium & $9300-9350$ & $269-331$ \\
\hline Copper & $4.19-4.55$ & $0.40-0.43$ \\
\hline Zinc & $2.08-2.25$ & - \\
\hline Selenium & - & $0.003-0.006$ \\
\hline Cobalt & $0.09-0.11$ & - \\
\hline Lead & 0.0092 & - \\
\hline Mercury & not indicated & - \\
\hline Arsenic & not indicated & - \\
\hline
\end{tabular}

${ }^{\mathrm{a}} \mathrm{Hu}$ and $\mathrm{Li}(2001)$

${ }^{\mathrm{b}}$ Bogdanov (2017)

In addition to organic substances, the homogenate is a source of important macro- and microelements. The test sample contained the most potassium, magnesium and sodium - an average of 9325,970 and $420 \mathrm{mg}$ per $100 \mathrm{~g}$ of the product, respectively. Also, there are following trace elements in the homogenate: iron, copper, manganese, zinc. There was no mercury and arsenic, and the lead content was within the concentrations acceptable by GOST R 56668-2015.

Comparing the obtained mineral composition with the results of studies by $\mathrm{Hu}$ and $\mathrm{Li}$ (2001) and Bogdanov (2017), it was revealed that the homogenate produced at the apiary of Taezhny Med LLC has several times more magnesium, potassium, sodium, calcium, copper and much less phosphorus. The data on the content of iron and manganese were in relative agreement. It can be assumed that such a large difference in the chemical composition of the homogenate is associated with the technology of its production, geographical conditions, and a number of other factors $[5,6]$.

\section{Conclusions}

Based on the research carried out, the following conclusions can be drawn:

1. Drone brood homogenate produced at the apiary of Taezhny Med LLC, Anuchinsky District, Primorsky Territory, meets the requirements of the Russian State Standard GOST R 56668-2015. It also has a high mass fraction of crude protein (44\%) and decenoic acids $(12.0 \%)$.

2. Comparative analysis of the actual chemical composition of the homogenate with the data of literature sources showed that only the content of moisture, iron, manganese and $\mathrm{pH}$ is relatively the same; for the rest of the analyzed parameters, a significant difference was observed.

3. In Russia and abroad, the quality indicators of drone homogenate are different. There is no single standard for this product, which can create certain difficulties when exporting (importing) and using it as a biologically active additive or for other purposes. 


\section{References}

1. R. Balkanska, I. Karadjova, M. Ignatova Comparative analyses of chemical composition of royal jelly and drone brood, Bulgarian Chemical Communications, 46, 412-416 (2014)

2. A.E. Belov, A.F. Ismagilova, The effectiveness of 9-oxo-2E-decenoic acid for the treatment of mastitis in cows and obtaining milk of high sanitary quality, J. Bulletin of the Bashkir State Agrarian University, 20-21 (2012)

3. M.S. Blum, A.F. Novak, S. Taber 10-hydroxy- $\Delta 2$-decenoic acid, an antibiotic found in royal jelly, Science, 130, 3373, 452-453 (1959)

4. L. Burmistrova, Physico-chemical analysis and biochemical appreciation of drone brood, PhD Thesis, Ryazan Medical University (1999)

5. S. Bogdanov, Bee product science: royal jelly, bee brood: composition, health, medicine: a review (2017)

6. F. Hu, Y. Li, Nutritive value and pharmacological actions of Italian worker bee larvae and pupae, In: Proceedings of the 37th International Apicultural Congress, 28 (2001)

7. V.A. Isidorov, S. Bakier, M. Stocki, GC-MS investigation of the chemical composition of honeybee drone and queen larva homogenate, J. Apic. Sci, 60, 111-120 (2016)

8. O. G. Kataev Investigation of the influence of drone brood homogenate on sexual maturation and morphogenesis of the sexual glands of pigs, Young scientists - in the science and practice of agro-industrial complex: proceedings of the international scientific and practical conference of young scientists, 61-62 (2018)

9. N.A. Kim, Improving the working capacity of service dogs, Topical issues and innovative technologies in veterinary medicine, animal husbandry and the nature protection complex: materials of the International scientific and practical research. conference, Part II, 210 (2019)

10. I.I. Klishina, Influence of drone brood on the activity of factors of nonspecific resistance and the functional state of the liver in acute intoxication: dis. Cand. Pharmaceutical Sciences: Pharmacology, Clinical Pharmacology (2020).

11. D. S. Lazaryan, Comparative amino acids analysis in bee brood Pharmaceutical Chemistry Journal, 36, 680-682 (2002)

12. D.S. Lazaryan, E.M. Sotnikova, Determining the content of sulphohydryl groups in bee brood proteins, Pharm. Chem. J. 37, 681-682 (2003)

13. SS.G. Mardanly, V.V. Pomazanov, V.A. Kiseleva, Ya.B. Neskorodov, Biological activity of the components of royal jelly and bee venom, J. Pharmacy \& Pharmacology, 6, 5, 419-439 (2018)

14. C.S. McCleskey, R.M. Melampy Bactericidal properties of royal jelly of the honeybee, Journal of Economic Entomology, 32, 4, 581-587 (1939)

15. D. V. Murav'ev, Drone homogenate in feeding egg hens Theory and practice of modern science: materials of the XVII international journal scientific and practical conference, 87-90 (2015)

16. Kozlov G, et al. Advances in Intelligent Systems and Computing, pp 676-684(2020) doi:10.1007/978-3-030-57453-6_64L

17. A. Osintseva, Homogenate of drone larvae in the diet of dogs Beekeeping, 10, 50-51 (2009) 
18. A. A. Sattarova Economically useful features of honeybees when using drone brood homogenate: dis. on the map. scientist. step. 06.02.10, Aigul Adisovna Sattarova; Federal state educational institution of higher education, 152 (2010)

19. R. Sawczuk, J. Karpinska, W. Miltyk What do we need to know about drone brood homogenate and what is known, Journal of Ethnopharmacology, 245, 5, (2019)

20. A.B. Seres, E. Ducza, M. Bathori, A. Hunyadi, Z. Beni, M. Dekany, J. Hajgos-Toth effect of honeybee drone milk in castrated rats: roles of methyl palmitate and methyl oleate, J. Ethnopharmacol., 153, 446-453 (2014)

21. A. A. Skolov, O. L. Yankina Composition, properties and application of drone larvae homogenate Innovations of young people - development of agriculture: Mat 52 of the interuniversity scientific student conference, 102-106 (2016)

22. A. Zheldak, O.L. Yankina, Some qualitative indicators of the homogenate of drone brood, Innovations of the young - for the development of agriculture: Mat 53 of the interuniversity scientific student conference, Part 1, 25-30 (2017) 